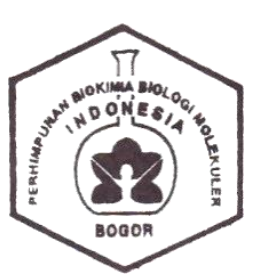

CURRENT BIOCHEMISTRY

ISSN: $2355-7877$

e-ISSN: 2355-7931

Journal homepage: http://journal.ipb.ac.id/index.php/cbj

Journal E-mail: current.biochemistry@gmail.com

\title{
The Efficiency of Melanoidin Based-Waste Degradation with Different Biological Methods
}

(Efisiensi Degradasi Limbah Berbahan Dasar Melanoidin dengan Berbagai Metode Biologis)

\author{
Hafizh Zahra $^{1 *}$, Ilham Kurniawan ${ }^{1}$, Abdurahman Hakim ${ }^{1}$ \\ ${ }^{1}$ Department of Biochemistry, IPB University, Bogor, 16680, Indonesia
}

Received: 1 November 2020 ; Accepted: 15 December 2020

Corresponding author : Hafizh Zahra; Departemen Biokimia IPB; e-mail: hafizh_zahra@apps.ipb.ac.id

\begin{abstract}
Each processing of palm fresh fruit bunches (FFB) into Crude Palm Oil (CPO) will produce solid and liquid waste. One of the forms of liquid waste produced is Palm Oil Mill Effluent (POME). POME waste can cause problems for the environment because it has physical characteristics of dark brown color, high density, rich in organic matter, and bad smell. The POME waste color is thought to come from melanoidin, a biopolymer pigment produced by the Maillard reaction of coconut processing. Apart from melanoidin, phenolic components are detected in POME waste, and this group of compounds is toxic. Several studies have shown that Lactobacillus plantarum can reduce the color of POME by $75 \%$. The decolorization process is thought to involve an enzyme as a waste color-changing agent. However, the efficiency associated with these events has not been further investigated. There are three main methods of melanoidin degradation, in that, biological, physicochemical, and enzymatic. This study used the PRISMA (Preferred Reporting Items for Systematic Reviews and Meta-Analyzes) approach in creating a short, concise, and clear summary through various references.
\end{abstract}

Keywords: Bioremediation, Melanoidin, Microbial Degradation

\begin{abstract}
ABSTRAK
Setiap proses pengolahan tandan buah segar (TBS) kelapa sawit menjadi Crude Palm Oil (CPO) akan memproduksi limbah dalam bentuk padat dan cair. Salah satu bentuk limbah cair yang dihasilkan tersebut adalah Palm Oil Mill Effluent (POME). Limbah POME dapat menimbulkan masalah bagi lingkungan karena memiliki ciri fisik berwarna coklat pekat, densitas tinggi, kaya bahan organik, dan berbau busuk. Warna dari limbah POME diduga berasal dari melanoidin, suatu pigmen biopolimer yang dihasilkan oleh reaksi Maillard olahan kelapa. Selain melanoidin, terdapat komponen fenolik yang terdeteksi dalam limbah POME, dimana kelompok senyawa ini bersifat toksik. Beberapa penelitian menunjukkan bahwa bakteri Lactobacillus plantarum dapat mengurangi warna POME sebesar 75\%. Proses dekolorisasi tersebut diduga melibatkan enzim sebagai agen pengubah warna limbah. Akan tetapi, efisiensi terkait peristiwa tersebut belum diselidiki lebih lanjut. Terdapat tiga metode utama dalam degradasi melanoidin seperti biologis, fisikokimia, dan enzimatis. Penelitian ini menggunakan metode PRISMA (Preferred Reporting Items for Systematic Reviews and Meta-Analyses) dalam menciptakan ringkasan yang singkat, padat, dan jelas melalui berbagai referensi.
\end{abstract}


Keywords: Bioremediasi, Degaradasi Mikrobial, Melanoidin

\section{PENDAHULUAN}

Melanoidin adalah senyawa berwarna coklat berstruktur polimer heterogen dengan berat molekul tinggi. Melanoidin terbentuk melalui reaksi Maillard dari kondensasi gula dan asam amino pada suhu tinggi dalam kandungan air yang rendah. Selain gula dan asam amino, terdapat beberapa senyawa yang dapat memengaruhi kepekatan warna melanoidin, diantaranya adalah asam asetat, asam laktat, asam piroglutamat, asam suksinat, dan asam format (Villaño et al. 2016). Selain reaksi Maillard, sintesis melanoidin juga terjadi saat proses karamelisasi (Rofiah \& Machfudz 2014). Melanoidin hadir dalam berbagai produk seperti roti, kecap, cuka, saus tomat, dan kopi. Golongan senyawa ini sulit terdegradasi jika telah mencemari lingkungan. Degradasi dapat terjadi apabila struktur melanoidin tersebut dimodifikasi oleh mikroba tertentu. Selain itu, melanoidin dapat berdampak pada penghambatan metaloprotease matriks yang berimplikasi pada pertumbuhan dan perkembangan tumor (Villaño et al. 2016).

Dampak senyawa melanoidin pada lingkungan dapat memberikan efek yang polutif, khususnya pada wilayah perairan seperti sungai, danau, dan laguna. Beberapa efek yang diberikan diantaranya adalah penurunan kualitas air, bioavailabilitas biota, pemblokiran laju fotosintesis, dan eutrofikasi (Singh et al. 2019). Hal tersebut dapat membahayakan flora dan fauna perairan mengingat senyawa ini sukar terdegradasi. Beberapa metode pemulihan polusi melanoidin yang telah diketahui yang diantaranya adalah dengan cara fisikokimia dan biologis (Gonzalo et al. 2016). Metode fisikokimia merupakan cara yang konvensional dalam pemulihan polusi melanoidin. Metode tersebut terdiri dari adsorpsi, flokulasi, atau koagulasi serta menggunakan bahan lain seperti $\mathrm{FeCl}_{3}, \mathrm{AlCl}_{3}$, dan karbon aktif pada metode adsorpsi. Akan tetapi, metode fisiko-kimia diketahui tidak efektif dalam bioremediasi karena senyawa melanoidin dapat mengalami repolimerasi dan memperburuk polusi yang ada (Singh et al. 2013). Dengan demikian, fokus penelitian terkini terkait penanggulangan limbah ini beralih ke metode biologis.

\section{METODOLOGI}

Kajian ini merupakan kajian sistematis dengan menggunakan item pelaporan yang disukai yaitu tinjauan sistematis dan metaanalisis, atau tinjauan sistematis yang disebut PRISMA, yang dilakukan secara sistematis dengan mengikuti prosedur atau protokol penelitian yang benar. Langkah-langkah pelaksanaan tinjauan sistematis telah direncanakan dan diatur dengan matang, sehingga metode ini sangat berbeda dengan metode yang digunakan hanya untuk menyampaikan penelitian pustaka. Proses tinjauan sistematis meliputi beberapa langkah, yaitu 1) penyusunan latar belakang dan tujuan, 2) pertanyaan penelitian, 3) pengambilan dokumen, 4) kriteria pemilihan, 5) penyaringan aktual, 6) quality checklist, 6) strategi ekstraksi data, 7) data strategi yang komprehensif. Jumlah penelusuran yang digunakan dalam ringkasan ini adalah sebanyak 36 buah.

\section{PEMBAHASAN}

\section{Metode Anaerobik dalam Bioremediasi Limbah Melanoidin}

Pengolahan limbah secara anaerobik merupakan salah satu proses ekstraksi energi dari komponen limbah tanpa menggunakan oksigen. Pengolahan limbah molase secara anaerobik memiliki keunggulan seperti menghasilkan sedikit lumpur (sludge), 
membutuhkan lebih sedikit energi, dan menghasilkan biogas yang dapat dimanfaatkan lebih lanjut. Salah satu sumber utama melanoidin berasal dari manufaktur penghasil kertas berupa limbah black liquor. Limbah ini merupakan produk samping reaksi Kraft ketika pulp kayu diubah menjadi bubur kertas. Reaksi ini mampu menghilangkan lignin, hemiselulosa, dan komponen ekstraktif lainnya untuk membebaskan serat selulosa. Menurut Nure et al. (2017), pengolahan secara anaerobik limbah black liquor dapat dilakukan dengan sistem Upflow Anaerobic Sludge Blanket Reactor (UASBR) yang membutuhkan waktu 509 hari. Proses-proses awal dari sistem pengolahan limbah ini masih mengandung $100 \%$ molase. Setelah beberapa tahapan inkubasi, sebanyak $30 \%$ dari chemical oxygen demand (COD) SWW mampu terdegradasi dengan baik. Akan tetapi, sistem UASBR tidak dapat melakukan perubahan komposisi media akhir limbah sehingga terjadi penurunan efisiensi penghilangan COD disertai produksi biogas yang tidak stabil. Dengan demikian, UASB tidak efektif digunakan sebagai pilihan remediasi dari untuk limbah black liquor (Qin et al. 2014).

Limbah kotoran hasil industri peternakan juga dapat menjadi sumber utama melanoidin. Penelitian Mora-Villalobos et al. (2020) menunjukkan bahwa pengolahan limbah ternak dengan kandungan gula yang tinggi dapat diremediasi menggunakan sistem Upflow Anaerobic Fixed Bed (UAFB). Remediasi dilakukan dengan menginokulasi reaktor dengan kultur anaerobik asal kotoran sapi, kotoran ayam, dan lumpur aktif pada 32$34^{\circ} \mathrm{C}$ dengan retensi waktu hidrolik selama 20 jam. Hasil menunjukkan bahwa sistem ini dapat menurunkan kadar COD hingga 2000$8000 \mathrm{mg} / \mathrm{L}$, namun belum terbukti efektif jika diterapkan dalam kondisi lingkungan tercemar yang sesungguhnya. Hasil yang berbeda ditunjukkan oleh penelitian Vejchar et al. (2019) melalui sistem UAFB yang sama. Hasil penelitian tersebut menunjukkan penurunan kandungan senyawa organik sebesar 75-93\%, namun reaktor terlebih dulu dimodifikasi dengan pelapisan ring pall standar dari polypropilen dengan luas permukaan $50 \mathrm{~m}^{2}$. Modifikasi tersebut menghasilkan efisiensi yang lebih baik dalam proses penurunan COD dibandingkan dengan reaktor yang dilapisi polietilen dan PVC. Variasi pengaruh waktu retensi hidrolik juga dilakukan selama 5-30 hari dan dievaluasi terhadap total chemical oxygen demand (TCOD). Penurunan total TCOD yang terjadi menghasilkan perbedaan sekitar 271-5286 mg/L dan kadar BOD sekitar 66-1212 mg/L jika dibandingkan dengan reaktor standar. Melalui angka tersebut, penghilangan TCOD dan BOD yang terjadi memiliki efisiensi sebesar 54-74\%. Selain itu, waktu retensi hidrolik yang paling efektif jatuh pada hari ke 30 dan pengaruhnya pada efisiensi penghilangan TCOD dan BOD mengikuti hubungan eksponensial.

\section{Metode Aerobik dalam Bioremediasi Limbah Melanoidin}

Pengolahan air limbah secara anaerobik masih mengandung polutan organik dengan konsentrasi tinggi dan kemudian tidak dapat dibuang secara langsung. Limbah yang diolah sebagian besar masih memiliki BOD, COD, dan padatan tersuspensi yang tinggi. Hal ini dapat mengurangi ketersediaan nutrisi dan mineral esensial melalui proses penjebakan dalam bentuk organik yang tidak dapat berpindah. Selain itu, proses ini juga dapat menghasilkan zat fitotoksik selama dekomposisinya. Oleh karena itu, pengolahan aerobik air limbah molase dapat dilakukan sebagai solusi alternatif penghilangan melanoidin, COD, dan BOD. Pemanfaatan mikroorganisme seperti bakteri (kultur murni dan campuran), sianobakteria, ragi, dan jamur diketahui mampu mendegradasi melanoidin dan penghilangan warna air limbah molase (Zhang et al. 2019). 


\section{Bioremediasi dengan Bakteri}

Banyak bakteri telah dilaporkan memiliki kemampuan dalam menghilangkan warna melanoidin. Bakteri asam laktat (Lactobacillus coryniformis, Lactobacillus sakei, Lactobacillus plantarum, Weisella soli, Pediococcus parvulus, Pediococcus pentosaceus) dapat digunakan untuk menghilangkan warna melanoidin (Omar et al. 2020). Isolat Lactobacillus plantarum menunjukkan $75 \%$ dekolorisasi melanoidin. Kryzwonos (2011) menggunakan konsorsium dari genus Bacilli untuk menghilangkan warna melanoidin. Selain itu, Yadav \& Chandra (2012) mengembangkan konsorsium Proteus mirabilis, Bacillus sp., Raoultella planticola dan Enterobacter sakazakii dengan perbandingan 4:3:2:1 yang bertanggung jawab atas $75 \%$ dekolorisasi melanoidin dalam 10 hari. Isolat Alcaligenes faecalis galur SAG5 menunjukkan $72.6 \%$ dekolorisasi melanoidin pada $\mathrm{pH}$ optimum 7.5 dan suhu $37^{\circ} \mathrm{C}$. Degradasi melanoidin sintetik dan alami dipelajari dengan menggunakan konsorsium aksenik dan campuran bakteri (Bacillus licheniformis, Bacillus sp. dan Alcaligenes sp.) serta menunjukkan konsorsium campuran lebih efektif dibandingkan dengan kultur aksenik dalam menghilangkan warna $73.7 \%$ dan $69.8 \%$ melanoidin sintetis dan alami. Di sisi lain, kultur aksenik menghilangkan warna masing-masing $65.88 \%, 62.5 \%$ dan $66.1 \%$ sintetis dan 52.6\%, $48.9 \%$ dan $59.6 \%$ melanoidin alami (David et al. 2015). Selanjutnya Wilk et al. (2019) mengisolasi Lactobacillus plantarum dari sampel acar di Thailand dan menunjukkan hasil dekolorisasi pigmen melanoidin tertinggi sebesar $68.12 \%$ dengan larutan MP mengandung glukosa $2 \%$, ekstrak ragi $0.4 \%, \quad \mathrm{KH}_{2} \mathrm{PO}_{4} \quad 0.1 \%$, $\mathrm{MgSO}_{4} \cdot 7 \mathrm{H}_{2} \mathrm{O} \quad 0.05 \%$ dan $\mathrm{pH}$ awal 6 dalam kondisi statis pada $30^{\circ} \mathrm{C}$ dalam waktu 7 hari.

Suryanti et al. (2015) melakukan dekolorisasi air limbah molase menggunakan sel Pseudomonas fluorescens dengan efisiensi dekolorisasi sebesar $76 \%$ dalam kondisi tidak steril (empat hari) pada suhu $30{ }^{\circ} \mathrm{C}$. Prakash et al. (2014) mempelajari degradasi air limbah penyulingan secara anaerob oleh tiga galur bakteri, yaitu Xanthomonas fragariae, Bacillus megaterium dan Bacillus cereus dan penghilangan COD meningkat dengan waktu hingga 48 jam. Penghilangan COD maksimum dan efisiensi penghilangan warna bervariasi dari $66-81 \%$ dan $65-75 \%$ untuk galur tersebut. Galur Bacillus cereus menunjukkan efisiensi maksimum penghilangan COD (81\%) dan warna $(75 \%)$ dari ketiga galur. Zhang et al. (2020) kemudian mempelajari lebih lanjut skrining anaerob fakultatif pembentuk asam untuk kemampuan penghilangan warna mereka dengan air limbah sulingan yang dihasilkan selama fermentasi alkohol dari tetes tebu. Sebanyak 113 galur yang diisolasi dari menunjukkan aktivitas penghilangan warna pada media GYP termodifikasi yang mengandung $10 \%$ (v/v) air limbah suling. Galur SM-3 menghilangkan warna $31.4 \%$ pigmen molase pada konsentrasi $10 \%$ (v/v) air limbah suling yang ditambah dengan glukosa $1 \%$ dalam waktu lima hari. Galur tersebut diidentifikasi sebagai kultur bakteri Lactobacillus casei. Sa'diyah et al. (2019) melakukan seleksi berbagai mikroorganisme yang memiliki kemampuan menghilangkan warna air limbah molase dalam kondisi termofilik dan anaerobik. Galur MD-32 dipilih sebagai galur terbaik dan termasuk genus Bacillus yang mirip dengan B. smithii. Galur tersebut dapat menghilangkan warna limbah $35.5 \%$ pigmen molase dalam waktu 20 hari pada suhu $55^{\circ} \mathrm{C}$.

\section{Bioremediasi dengan Fungi}

Aktivitas dekolorasi oleh mikroba telah banyak diteliti pada limbah molase. Salah satu fungi yang diketahui mampu mendegradasi dan dekolorasi limbah cairan adalah keluarga Aspergillus seperti Aspergillus fumigatus G26, Aspergillus niger, Aspergillus niveus. Spesies 
Aspergillus fumigatus UB260 mampu menghilangkan $69-75 \%$ zat warna melanoidin serta mengurangi COD sebanyak 70-90\%. Rhizoctonia sp. 90 mampu mendekolorasi medium melanoidin molase dan medium melanoidin sintetik sebanyak $87.5 \%$ dan 84.5\% secara berurutan (Hwang et al. 2011). Selain itu, Aspergilus awamori var. kawachi juga telah banyak digunakan untuk produksi protein sel tunggal dari limbah perairan Jepang setelah kultivasi aerobik (Vítězová et al. 2020). Jamur pelapuk putih juga diketahui dapat menghilangkan warna melanoidin yang terkandung dalam limbah air (Chuppa-Tostain et al. 2020). Phanerochaete chrysosporium mampu menghilangkan warna dan total fenol dari efluen pemurnian gula. Beberapa faktor yang diduga mempengaruhi aktivitas deolorasi meliputi konsentrasi nutrien, $\mathrm{pH}$, dan sumber karbon. Penambahan $\mathrm{MgSO}_{4}, \mathrm{KH}_{2} \mathrm{PO}_{4}$, $\mathrm{NH}_{4} \mathrm{NO}_{3}$, dan smber karbon dapat memaksimalkan eliminasi warna sebesar $69 \%$.

Fungi jenis lain, Coriolus No.20 yang tergabung dalam kelas basidiomiset, dapat menghilangkan zat warna pada limbah air molase sebanyak $82.5 \%$ dalam kondisi optimal. Dekolorasi ini terjadi melalui penyerapan melanoidin ke dalam miselium. Galur ini, dalam sistem fed-batch, mampu menghilangkan warna sebanyak $75 \%$. Dekolorasi oleh fungi juga dapat dibantu oleh enzim mangan peroksidase $(\mathrm{MnP})$ dan mangan-independen peroksidase (MIP). Kedua enzim ini menunjukkan adanya aktivitas dekolorasi terhadap melanoidin jika terdapat $\mathrm{H}_{2} \mathrm{O}_{2}$. Miyata et al. (2000) memanfaatkan jamur pelapuk putih tipe Coriolous hirsutus yang menunjukkan adanya kemampuan dekolorasi melanoidin dalam kultur yang tidak diberi tambahan nutrien nitrogen. Penambahan pepton pada kultur mengurangi kemampuan fungi untuk mendekolorasi melanoidin, namun nitrogen anorganik, contohnya ammonium dan nitrat, tidak mengurangi kemampuan dekolorasi fungi tersebut. Isolat
Phanerochaete chrysosporium JAG-40 dari sampel tanah yang jenuh dengan limbah molase mampu mendekolorasi melanoidin alami dan sintetik sebanyak $80 \%$ selama 6 hari pada suhu $30^{\circ} \mathrm{C}$ dalam kondisi aerobik (Vejchar et al. 2019). Kromatografi filtrasi gel menunjukkan bahwa melanoidin dengan bobot molekul lebih besar akan didekolorasi lebih cepat dibandingkan fraksi melanoidin dengan bobot molekul kecil.

Brunner et al. (2018) melaporkan bahwa Flavodon flavus, spesies basidiomiset yang diisolasi dari habitat perairan, mampu menghilangkan warna kecoklatan yang tinggi pada molase. Aktivitas dekolorasi dari fungi ini diduga dapat ditingkatkan dengan cara imobilisasi dalam busa poliuretan. Aktivitas dekolorasi juga ada pada media yang ditambahkan air laut, media rendah nitrogen, media kaya nutrient, dan media bagas tebu. España-Gamboa (2017) mengisolasi dua galur fungi, yaitu Penicillium pinophilum TERI DB1 dan Alternaria gaisen TERI DB6 yang mengandung enzim ligninolitik dan berpotensi mendekolorasi efluen yang terkontaminasi. Adapun enzim yang terkandung dalam fungi ini meliputi lakase, mangan-dependen peroksidase, dan lignin peroksidase. Studi lain menunjukkan Trichoderma viride dapat menghilangkan warna sebanyak $53.5 \%$ ketika dikultivasi selama 7 hari pada suhu $30^{\circ} \mathrm{C}$. Dekolorasi dapat meningkat dengan adanya penambahan pepton dan ekstrak khamir pada media produksi. Penurunan $\mathrm{pH}$ dibawah 5 setelah inkubasi juga diketahui dapat meningkatkan aktivitas dekolorasi. Meski terlihat adanya korelasi antara gula pereduksi dan penurunan intensitas warna, namun pengaruh penggunaan enzim pada aktivitas dekolorasi belum diketahui.

\section{Metode Enzimatis dalam Bioremediasi Limbah Melanoidin \\ Bioremediasi enzimatik berada diantara proses perawatan fisikokimia dan biologis.}


Bioremediasi enzimatik memiliki keunggulan teknologi dan membutuhkan pertimbangan ekonomis untuk mengaplikasikannya dalam skala besar. Proses ini memiliki beberapa keunggulan potensial dibandingkan pengobatan konvensional seperti dapat diterapkan pada senyawa biorefraktori, dapat dilakukan baik pada konsentrasi kontaminan tinggi atau rendah, dapat diaplikasikan pada berbagai $\mathrm{pH}$, suhu, dan salinitas (Echavarría et al. 2012). Penelitian terkini berfokus pada pengembangan proses enzimatik untuk pengolahan limbah cair sebagai pengakuan atas potensi proses ini (Arimi et al. 2015). Sejumlah besar enzim (peroksidase, oksidoreduktase, enzim selulolitik sianidase, protease, dan amilase) dari berbagai sumber telah dilaporkan berperan penting dalam berbagai aplikasi pengolahan limbah.

Prabhakar et al. (2015) memperoleh dekolorisasi maksimum sekitar $60 \%$ pada hari ke-8 setelah inokulasi dengan jamur Trametes $s p$. Penelitian tersebut menunjukkan bahwa efluen yang ditambahkan pada konsentrasi akhir 20\% (v/v) setelah lima hari pertumbuhan jamur memiliki aktivitas lakase tertinggi dalam miselium ekstraseluler. Basidiomisetes jenis T. versicolor juga mampu mengurai asam humat dan turunannya serta melanoidin. Sebuah protein ekstraseluler sebesar $47 \mathrm{kDa}$ hasil isolasi Rawel et al. 2019 dari $T$. versicolor yang belum diidentifikasi hingga saat ini dapat memineralisasi melanoidin. Proses tersebut dapat dikaitkan erat dengan metabolisme fungi yang ada. Sistem enzim yang bergantung pada $\mathrm{Mn}^{2+}$ ini membutuhkan oksigen dan digambarkan sebagai peroksidase. Beberapa penelitian telah mengidentifikasi enzim terkait degradasi lignin yang berpartisipasi dalam dekolorisasi melanoidin (Georgiou et al. 2016).

Glukosa oksidase penghasil $\mathrm{H}_{2} \mathrm{O}_{2}$ intraseluler telah diisolasi dari galur Coriolus. Selain itu, C. hirsustus telah dilaporkan menghasilkan enzim yang mengkatalisis dekolorisasi melanoidin secara langsung tanpa penambahan gula dan $\mathrm{O}_{2}$ (Kong 2016). Miyata et al. (2000) menggunakan pelet $C$. hirsutus untuk menghilangkan warna media yang mengandung melanoidin. Telah dijelaskan bahwa $\mathrm{H}_{2} \mathrm{O}_{2}$ ekstraseluler dan dua peroksidase ekstraseluler, mangan-independen peroxidase (MIP) dan mangan peroxidase (MnP) terlibat dalam aktivitas dekolorisasi (Dedeles et al. 2010). Gupta et al. (2011) menyelidiki peroksidase penghilang warna dengan membudidayakan Candida sp. menggunakan molase sebagai sumber karbon. Komponen dalam medium molase merangsang produksi peroksidase penghilang warna, namun menghambat aktivitas penghilangan warna dari enzim yang dimurnikan (Vrsanska 2016). Dekolorisasi enzimatik dari media molase juga telah menggunakan $P$. chrysosporium BW808 (Saoji \& Khan 2015). Dalam kondisi stasioner, tidak ada galur yang dapat menghilangkan warna molase atau menghasilkan enzim lignin peroksidase, mangan peroksidase, dan lakase (Kumar \& Chandra 2018). Akan tetapi, semua galur baru dapat menghasilkan lignin peroksidase dan mangan peroksidase bila dibudidayakan dalam botol kaca beralas datar dalam kondisi budidaya stasioner.

Dalam beberapa dekade terakhir, perkembangan minat di bidang bioremediasi melanoidin menggunakan mikroba telah meningkat. Beberapa mikroorganisme seperti bakteri dan jamur menunjukkan kemampuan yang baik dalam menghilangkan warna limbah industri penyulingan berbasis melanoidin. Dengan demikian, pemahaman yang lebih baik tentang aktivitas mikroba yang bertanggung jawab atas degradasi melanoidin akan berkontribusi untuk meningkatkan efisiensi sistem bioremediasi limbah secara keseluruhan. Selain itu, adalah penting untuk mengetahui produk akhir dari bioremediasi melanoidin. Perbaikan genetik isolat dapat dieksplorasi di masa depan untuk meningkatkan efisiensi penghilangan warna 
mereka. Upaya penelitian yang lebih maju secara teknis diperlukan untuk mencari, mengeksploitasi spesies bakteri baru, dan meningkatkan aplikasi praktis untuk menyebarkan penggunaan bakteri untuk bioremediasi limbah industri. Studi enzimatik akan digunakan untuk memahami mekanisme degradasi melanoidin di prospek masa depan. Terakhir, bioremediasi mikroba yang melibatkan kombinasi ahli mikrobiologi, ahli bioteknologi, ahli kimia, dan insinyur sangat ideal untuk menutupi kesenjangan yang semakin lebar antara disiplin ilmu yang berbeda.

\section{DAFTAR PUSTAKA}

Arimi MM, Zhang Y, Götz G, Geißen SU. 2015. Treatment of melanoidin wastewater by anaerobic digestion and coagulation. Environmental Technology. 36(19): 2410-2418.

Brunner I, Fischer M, Rüthi J, Stierli B, Frey B. 2018. Ability of fungi isolated from plastic debris floating in the shoreline of a lake to degrade plastics. PloS one. 13(8): 1-14.

Chuppa-Tostain G, Tan M, Adelard L, ShumCheong-Sing A, François JM, Caro Y, Petit T. 2020. Evaluation of filamentous fungi and yeasts for the biodegradation of sugarcane distillery wastewater. Microorganisms. 8(10): 1-16.

David C, Arivazhagan M, Balamurali MN, Shanmugarajan D. 2015. Decolorization of distillery spent wash using biopolymer synthesized by Pseudomonas aeruginosa isolated from tannery effluent. BioMed Research International. 1(2015): 1-10.

Dedeles GR, Cordero PR, Tanaka M, Asano K. 2010. Color reduction of molassesbased distillery slop by crude manganese peroxidase from Ganoderma lucidum. Asia Life Sciences-The Asian International Journal of Life Sciences. 19(2): 215-227.
Echavarría AP, Pagán J, Ibarz A. 2012. Melanoidins formed by Maillard reaction in food and their biological activity. Food Engineering Reviews. 4(4): 203-223.

España-Gamboa E, Vicent $\mathrm{T}$, Font $\mathrm{X}$, Dominguez-Maldonado J, Canto-Canché B, Alzate-Gaviria L. 2017. Pretreatment of vinasse from the sugar refinery industry under non-sterile conditions by Trametes versicolor in a fluidized bed bioreactor and its effect when coupled to an UASB reactor. Journal of Biological Engineering. 11(1): 1-11.

Georgiou RP, Tsiakiri EP, Lazaridis NK, Pantazaki AA. 2016. Decolorization of melanoidins from simulated and industrial molasses effluents by immobilized laccase. Journal of Environmental Chemical Engineering. 4(1): 1322-1331.

Gonzalo G, Colpa DI, Habib MH, Fraaije MW. 2016. Bacterial enzymes involved in lignin degradation. $\mathrm{J}$ Biotechnol. 20(236): 110-119.

Gupta M, Mishra PK, Kumar A, Tiwari S. 2011. Decolorization of molasses melanoidin by Candida Sp. Indian Journal of Applied and Pure Biology. 26(2): 199-204.

Hwang CF, Jiang YS, Sheu SC, Hsieh PC, Guo JH. 2011. Purification and characterization of a novel glucose oxidase-like melanoidin decolorizing enzyme from Geotrichum sp. No. 56. African Journal of Microbiology Research. (20): 3256-3266.

Kong W, Chen H, Lyu S, Ma F, Yu H, Zhang X. 2016. Characterization of a novel manganese peroxidase from white-rot fungus Echinodontium taxodii 2538, and its use for the degradation of ligninrelated compounds. Process Biochemistry. 51(11): 1776-1783.

Kryzwonos M. 2011. Decolorization of sugar beet distillery effluent using mixed cul tures of bacteria of the genus Bacillus. 
African Journal of Biotechnology. 11(14): 3464-3475.

Kumar V, Chandra R. 2018. Characterisation of manganese peroxidase and laccase producing bacteria capable for degradation of sucrose glutamic acidMaillard reaction products at different nutritional and environmental conditions. World Journal of Microbiology and Biotechnology. 34(2): 1-18.

Miyata N, Mori T, Iwahori K, Fujita M. 2000. Microbial decolorization of melanoidin containing wastewaters: combined use of activated sludge and the fungus Coriolus hirsutus. Journal of Bioscience and Boengineering. 89(2):145-150.

Mora-Villalobos JA, Montero-Zamora J, Barboza N, Rojas-Garbanzo C, Usaga J, Redondo-Solano M, Schroedter L, Olszewska-Widdrat A, López-Gómez JP. 2020. Multi-product lactic acid bacteria fermentations: A review. Fermentation. 6(1): 1-21.

Nure JF, Shibeshi NT, Asfaw SL, Audenaert W, Van Hulle SW. 2017. COD and colour removal from molasses spent wash using activated carbon produced from bagasse fly ash of Matahara sugar factory, Oromiya region, Ethiopia. Water SA. 43(3): 470-479.

Omar AA, Mahgoub S, Salama A, Likotrafiti E, Rhoades J, Christakis C, Samaras P. 2020. Evaluation of Lactobacillus kefiri and manganese peroxidase producingbacteria for decolorization of melanoidins and reduction of chemical oxygen demand. Water and Environment Journal.

Prabhakar S, Kandeepan C, Sivamani P. 2015. Analysis on Various Enzymes involved in Biodegradation of Lignocellulose by Fungal Isolates from Wood and Soil. International Journal of Recent Scientific Research. 5(11): 2053-2057.

Prakash NB, Sockan V, Raju VS. 2014. Anaerobic digestion of distillery spent wash. ARPN Journal of Science and Technology. 4(3): 134-140.

Qin X, Zhang J, Zhang X, Yang Y. 2014. Induction, purification and characterization of a novel manganese peroxidase from Irpex lacteus CD2 and its application in the decolorization of different types of dye. PLoS One. 9(11): $1-13$.

Rawel HM, Huschek G, Sagu ST, Homann T. 2019. Cocoa bean proteinsCharacterization, changes and modifications due to ripening and postharvest processing. Nutrients. 2019 Feb;11(2): 1-20.

Rofiah A, Machfudz A. 2014. Kajian dosis sukrosa dan sirup glukosa terhadap kualitas permen karamel susu. Nabatia. 11(1) 55-65.

Sa'diyah L, Lestari KA. 2019. Pengaruh variasi $\mathrm{pH}$ terhadap kemampuan bakteri dalam dekolorisasi limbah cair gula rafinasi. Pijar MIPA. 14(1): 73-76.

Santal AR, Singh N. 2013. Biodegradation of Melanoidin from Distillery Effluent: Role of Microbes and Their Potential Enzymes.

Saoji SA, Khan Z. 2015. Enzymatic clarification and fading of synthetic and real melanoidins by laccase and peroxidases in submerged fermentation by Phanerochaete chrysosporium BW808 (MTCC 787). Arch Appl Sci Res. 2015(70): 59-67.

Singh R, Singh TA, Singh T, Gaur R, Pandey PK, Jamal F, Bansal S, Pandey LK, Sarsaiya S, Nagpure J, Mishra S. 2019. Origin and Remediation of Melanoidin Contamination in Water Sources. Int J Curr Microbiol App Sci 8(2): 13991415.

Singh TA, Singh T, Singh R, Pandey PK, Gaur R, Jamal F, Patel SK, Bansal S. 2013. Bioremediation of melanoidin contamination in distillery effluent using Aspergillus brasiliensis. Biotechnologia. 101.3(2020): 205-213. 
Suryanti V, Marliyana SD, Wulandari A. 2015. Biosurfactant production by Pseudomonas fluorescens growing on molasses and its application in phenol degradation. InAIP Conference Proceedings. 1699(1):1-7.

Vejchar D, Vacek J, Hájek D, Bradna J, Kasal P, Svobodová A. 2019. Reduction of surface runoff on sloped agricultural land in potato cultivation in de-stoned soil. Plant, Soil and Environment. 65(3): 118-124.

Villaño D, García-Viguera C, Mena P. 2016. Colors: health effects. Encyclopedia of Food and Health. 265-272.

Vítězová M, Kohoutová A, Vítěz T, Hanišáková N, Kushkevych I. 2020. Methanogenic microorganisms in industrial wastewater anaerobic treatment. Processes. 8(12): 1-27.

Vrsanska M, Voberkova S, Langer V, Palovcikova D, Moulick A, Adam V, Kopel P. 2016. Induction of laccase, lignin peroxidase and manganese peroxidase activities in white-rot fungi using copper complexes. Molecules. 21(11): 1-15.

Wilk M, Krzywonos M, Borowiak D, Seruga P. 2019. Decolourization of sugar beet molasses vinasse by lactic acid bacteriathe effect of yeast extract dosage. Polish Journal of Environmental Studies. 28(1): 385-392.

Yadav S, Chandra R. 2012. Biodegradation of organic compounds of Molasses Melanoidin (MM) from Biomethanated Distillery Spent Wash (BMDS) during the decolorization by a potential bacterial consortium. Biodegradation. 1(1): 23-609.

Zhang W, Lin Z, Pang S, Bhatt P, Chen S. 2020. Insights into the biodegradation of lindane ( $\gamma$-hexachlorocyclohexane) using a microbial system. Frontiers in Microbiology. 11(522): 1-22.

Zhang Z, Li D, Zhang X. 2019. Enzymatic decolorization of melanoidins from molasses wastewater by immobilized keratinase. Bioresource Technology. 1(280): 165-172. 